Access to Justice in Eastern Europe,

Issue 2/3 (7) 2020

ISSN 2663-0575 (Print)

ISSN 2663-0583 (Online)

http://ajee-journal.com

10.33327/AJEE-18-3.2-3

O Rozhnov 'Towards Timely Justice

in Civil Matters Amid the COVID-19

Pandemic' (2020) 2-3 (7)

Access to Justice in Eastern Europe 100-114.

10.33327/AJEE-18-3.2-3-a000028

\title{
TOWARDS TIMELY JUSTICE IN CIVIL MATTERS AMID THE COVID-19 PANDEMIC ${ }^{*}$
}

\author{
Rozhnov Oleh \\ PhD (Law), Assoc. Prof. at Civil Procedure Department \\ Yaroslav Mudryi National Law University \\ Kharkiv, Ukraine
}

Summary: - 1. Introduction. - 2. Accessibility of Justice in Civil Cases and Procedural Time Limits: General Principles. - 3. Observation of Procedural Time Limits under Quarantine Conditions: Experience of Ukrainian Legislation and National Courts. 4. Concluding Remarks.

This article is devoted to the analysis of procedural time limits transformation under pandemic conditions implemented in the legislation of Ukraine during the coronavirus pandemic of 2020, as well as the practice of their application in national courts. It is stated that inaccuracy and incompleteness in resolving important issues related to the extension and renewal of procedural time for the administration of justice under the quarantine

Received: 16.06.2020. Revised: 08.07.2020. Approved: 14.08.2020

(C) 2020 Access to Justice in Eastern Europe and Oleh Rozhnov.

This work is licensed under a CC BY NC ND 4.0 license.

This is an Open Access publication distributed under the terms of the Creative Commons Attribution 4.0 International License, which permits to copy and distribute the material in any medium or format in unadapted form only, for noncommercial purposes only, and only so long as attribution is given to the creator. 
creates obstacles to the implementation of the main tasks of civil proceedings. Inaccuracy in the regulation by procedural legislation of certain procedural terms, the possibility of their renewal and extension can significantly affect the movement of all civil proceedings as well as significantly impede the achievement of its goals.

Keywords: procedural time, civil justice, access to justice, pandemic challenges, a fair and timely trial, COVID-19, civil litigation.

\section{INTRODUCTION}

Access to justice consists in the inadmissibility of the state to establish any obstacles to justice. In order to exercise the right to justice, the person concerned carries out procedural actions, the ultimate purpose of which are the timely consideration and resolution of civil cases. Thus, access to a specific procedural action and the timely administration of justice consider as the interrelated components of the concept of 'access to justice.'

It should be noted that interpreting the provisions of the Convention for the Protection of Human Rights and Fundamental Freedoms (hereinafter - Convention) the European Court of Human Rights (hereinafter - ECtHR) stated in its judgments that the right of access to justice is not absolute and may be limited: the right of access to the courts is not absolute but may be subject to limitations; these are permitted by implication since the right of access "by its very nature calls for regulation by the State, regulation which may vary in time and in place according to the needs and resources of the community and of individuals' (Case of Golder v. The United Kingdom, ${ }^{2}$ Case of Ashingdane v. the United Kingdom). ${ }^{3}$

The ECtHR allows the introduction of time limits, while it disallows the retrospective application of procedural law, which reduces the time to appeal against court (Melnyk v. Ukraine). ${ }^{4}$ As it was stated by ECtHR, in every case, the court should verify whether the reasons for renewal of a time-limit for appeal could justify the interference with the principle of res judicata (Ponomaryov v. Ukraine $)^{5}$.

The timeliness of civil proceedings is one of the most important elements of access to justice and one of the most pressing issues. ${ }^{6}$ In the face of modern challenges,

1 See the Convention for the Protection of Human Rights and Fundamental Freedoms Council of Europe, European Convention for the Protection of Human Rights and Fundamental Freedoms [1950] ETS 5 $<$ https://www.echr.coe.int/Documents/Convention_ENG.pdf > accessed 08 July 2020; OM Ovcharenko, Dostupnist pravosuddia ta garantii ioho realizatsii [Access to justice and guarantees of its implementation] (Pravo 2008) <http://library.nlu.edu.ua/POLN_TEXT/KNIGI/MonoOvcharenko.pdf> accessed 08 July 2020; NY Sakara, The problem of access to justice in civil matters [Problema dostupnosti pravosuddia $u$ tsyvilnykh spravah] (Pravo 2010).

2 Golder $v$. the United Kingdom (App no 4451/70) ECHR 21 February $1975<$ http://hudoc.echr.coe.int/ eng?i=001-57496> accessed 08 July 2020.

3 Ashingdane v. the United Kingdom (App no 8225/78) ECHR 28 May 1985 par. 34-35 <http://hudoc.echr. coe.int/eng?i=001-57425> accessed 22 June 2020.

4 Melnyk v. Ukraine (App no 23436/03) ECHR 28 March 2006 note 49, \$30. < http://hudoc.echr.coe.int/ eng?i=001-72888 $>$ accessed 08 July 2020.

5 Ponomaryov v. Ukraine (App no 3236/03) ECHR 3 April 2008 para $41<$ http://hudoc.echr.coe.int/ fre? $\mathrm{i}=001-85683>$ accessed 08 July 2020.

6 Sakara (n 1$)$. 
pandemics in particular, ways to ensure the reasonable timing of proceedings should receive considerable attention. The long duration of a trial may result in the trial being nullified, as the protection of rights, freedoms or interests will either lose relevance to the person applying to the court or the case will no longer be enforceable, as a result of the destruction of the subject matter of the dispute or a change in the external circumstances of the decision; either way, the actual protection of rights will not be exercised. In this regard, amendments to the legislation of Ukraine aimed at providing additional social and economic guarantees in connection with the spread of coronavirus disease (COVID-19) by extending the procedural time limits should be considered effective and sufficient to avoid violations of the Convention.?

The issues of granting a retroactive effect to regulations in connection with the amendments to procedural codes are worth particular attention. Thus, the Venice Commission notes that the retroactive effect of law is contrary to the principle of legal certainty, at least in criminal law (Art. 7 of the Convention), as the subjects of law must know the consequences of their behavior; but this also applies to civil and administrative law, to the extent that it negatively affects the rights and legitimate interests of an individual. ${ }^{8}$

On 11 March 2020, the World Health Organization announced that the epidemic of the COVID-19 virus, which was first identified in December 2019 in Wuhan, China, had reached a pandemic level. The coronavirus has affected all aspects of life and the legal system is no exception. ${ }^{9}$

The current viral pandemic poses real and obvious challenges to the effective and fair functioning of the courts. Remote access to justice has become a necessity and it is the responsibility of all involved to ensure that such hearings are properly provided in order to grant access to justice. ${ }^{10}$

On 10 June, the European Commission on the Efficiency of Justice (CEPEJ) during a special correspondence plenary meeting approved the Declaration 'Lessons Learned and Challenges Faced by the Judiciary during and after the COVID-19 Pandemic."11 This Declaration states that the current crisis in the judiciary requires an immediate and urgent response. At the same time, any measures that must be taken to overcome the crisis and its consequences must be in strict compliance with the principles of the rule of law and must respect and protect human rights. Any implemented measures must have a fixed end date, and a judicial review must take place within a specified time.

$7 \quad$ Khlebik v. Ukraine (App no 2945/16) ECHR 25 July $2017<$ https://hudoc.echr.coe.int/rus\#\{\%22item id\%22:[\%22001-175656\%22]\}> accessed 08 July 2020.

8 Venice Commission, Report on the Rule of Law adopted by the at its 86th plenary session (Venice, 25-26 March 2011) CDL-AD 003rev <https://www.venice.coe.int/webforms/documents/default. aspx?pdffile $=$ CDL-AD(2011)003rev-e $>$ accessed 08 July 2020.

9 World Health Organization Regional Office for Europe, 'WHO announces COVID-19 outbreak a pandemic' (Statement by Dr Hans Henri P Kluge, WHO Regional Director for Europe) <https://www. euro.who.int/en/health-topics/health-emergencies/coronavirus-covid-19/news/news/2020/3/whoannounces-covid-19-outbreak-a-pandemic> accessed 08 July 2020.

10 J Hayden, 'Remote Access to the Court of Protection Guidance', 31 March $2020<$ https://www.judiciary.uk/ wp-content/uploads/2020/04/20200331-Court-of-Protection-Remote-Hearings.pdf > accessed 08 July 2020.

11 CEPEJ, 'Lessons Learnt and Challenges Faced by the Judiciary during and after the COVID-19 Pandemic' (10 June 2020) CEPEJ 8rev) <https://rm.coe.int/declaration-en/16809eale2> accessed 08 July 2020. 
Nevertheless, across the world civil justice faces the unpredictable issues of preserving timely procedures ${ }^{12}$, without exception of Ukraine.

Quarantine has been implemented in Ukraine since 12 March 2020. ${ }^{13}$ Like other state bodies, after the introduction of quarantine, the courts began to reorganize their work. On 2 April 2020, the Law of Ukraine № 540-IX 'On Amendments to Certain Legislative Acts of Ukraine Aimed at Providing Additional Social and Economic Guarantees in Connection with the Spread of Coronavirus Disease (COVID-19)' of 30 March 2020 (hereinafter Law № 540-IX) came into force. ${ }^{14}$ At the same time, Law № 540-IX regulated the relations concerning the holding of a court session by videoconference outside the court premises and the extension of the procedural time for the period of the quarantine.

According to sub-clause 3 of Clause 12 of Section XII of the 'Final Provisions' of the said Law № 540-IX, to prevent the spread of coronavirus disease (COVID-19) during the quarantine established by the Cabinet of Ministers of Ukraine procedural time is extended for the length of the current quarantine.

The term of quarantine is established by the Resolution of the Cabinet of Ministers of Ukraine of 11 March 2020 №211,15 - throughout Ukraine starting from 12 March up to 3 April. The quarantine established by this Resolution was extended several times throughout the territory of Ukraine and according to the latest changes introduced by the Resolution of the Cabinet of Ministers №500 of 17 June 2020, ${ }^{16}$ the quarantine has now been extended until 31 July 2020.

On 18 June 2020, the Law of Ukraine 'On Amendments to Certain Legislative Acts of Ukraine Concerning the Procedural Time During the Quarantine Established by the Cabinet of Ministers of Ukraine to Prevent the Spread of Coronavirus Disease (COVID-19)' (hereinafter referred to as Law № 731-IX) entered into force ${ }^{17}$, according to which the grounds and procedure for renewal and extension of procedural time have been changed In particular, a new version of paragraph 3 of Section XII 'Final Provisions' of the Civil Procedure Code of Ukraine (hereinafter - CPC of Ukraine) was proposed, according to which during the quarantine, the court may renew the

12 Hermes Zaneti Jr, 'COVID-19: Brazilian Perspective' in Bart Krans and others, Civil Justice and COVID-19 (2020) 5 Septentrio Reports 8-10 <https://septentrio.uit.no/index.php/SapReps/issue/ view/465/entire> accessed 08 July 2020; Catherine Piché, 'The Canadian Justice System's Response to COVID-19' in Bart Krans and others, Civil Justice and COVID-19 (2020) 5 Septentrio Reports 11-12 <https://septentrio.uit.no/index.php/SapReps/issue/view/465/entire> accessed 08 July 2020.

13 The Resolution of the Cabinet of Ministers of Ukraine of 11 March 2020 № 211 'On prevention of the spread of coronavirus COVID-19 on the territory of Ukraine' <https://zakon.rada.gov.ua/laws/ show/211-2020-\%D0\%BF\#Text> accessed 08 July 2020.

14 The Law of Ukraine 'On Amendments to Certain Legislative Acts of Ukraine Aimed at Providing Additional Social and Economic Guarantees in Connection with the Spread of Coronavirus Disease (COVID-19)' [2020] Vidomosti of the Verkhovna Rada 18/123 < https://zakon.rada.gov.ua/laws/ show/540-IX\#Text> accessed 08 July 2020.

15 Resolution (n 13).

16 The Resolution of the Cabinet of Ministers of Ukraine of 17 June 2020 № 500 'On Amendments to Certain Acts of the Cabinet of Ministers of Ukraine' <https://zakon.rada.gov.ua/laws/show/500-2020$\%$ D0\%BF\#Text> accessed 08 July 2020.

17 The Law of Ukraine 'On Amendments to Certain Legislative Acts of Ukraine Concerning the Procedural Time of Quarantine Established by the Cabinet of Ministers of Ukraine for the Prevention of the Spread of Coronavirus Disease (COVID-19)' <https://zakon.rada.gov.ua/laws/show/731-IX\#Text> accessed 08 July 2020. 
procedural time established by the provisions of this Code, and if it recognizes the reasons for their default as valid and due to the restrictions imposed in connection with the quarantine. The applicant in this case should be the participants and persons who did not participate in the case, if the court has decided on their rights, interests and (or) obligations (provided they have the right to perform the relevant procedural actions under this Code). The court may renew the relevant time both before and after its expiration. Upon the application by a person, the court shall extend the procedural time established by the court, if the impossibility to perform the relevant procedural action within the specified time is due to the restrictions imposed by the quarantine. In addition, the procedure for extending procedural time which has previously been automatically extended has been established.

Thus, in accordance with the final and transitional provisions of the Law № 731-IX,18 procedural time, which was extended in accordance with Law № 540-IX of 30 March 2020, expires 20 days after the entry into force of this Law. During this 20-day period the parties to the case and persons who did not participate in the case have the right to extend the procedural time on the grounds established by this Law, if the court has decided on their rights, interests and (or) responsibilities (provided they have the right to take appropriate procedural actions under these codes).

To this end, this article attempts to analyze the procedural measures of immediate response, which were introduced in Ukraine during the quarantine, in order to ensure access to justice - a basic principle of the rule of law.19 Based on the above, the purpose of this article is to study the approach to the transformation of procedural time under conditions of a pandemic, implemented in the legislation of Ukraine during the quarantine of 2020 , as well as the practice of its application in national courts. The conclusions offer some lessons to improve this approach, provided that the person's right to a fair trial is ensured.

\section{ACCESSIBILITY OF JUSTICE IN CIVIL CASES AND PROCEDURAL TIME LIMITS: GENERAL PRINCIPLES}

Procedural time in accordance with Art. 120 of the CPC of Ukraine is primarily a period of time determined by law or the court to perform procedural actions by the parties and other participants in the proceedings.

According to Art. 121 of the $\mathrm{CPC}$, the court must set reasonable time limits for procedural actions. A time limit is reasonable if, taking into account the circumstances of the case, it provides for sufficient time to accomplish a procedural action and corresponds to the task of civil proceedings. The specified norm establishes the requirement for the court which will set a reasonable timeframe for the commission of the procedural action. In assessing the reasonableness of procedural time limits, the court setting the time limit must take into account: first, the sufficiency of the period of time determined by

18 Law (n 17).

19 United nations and the Rule of Law, 'Access to Justice' <https:/www.un.org/ruleoflaw/ru/thematic-areas/ access-to-justice-and-rule-of-law-institutions/access-to-justice/> accessed 08 July 2020. 
it to commit a procedural action, taking into account the circumstances of the case, secondly, the procedural time established by the court must correspond to the task of civil proceedings (Part 2 of Art. 121 of the CPC).

The court's determination of the sufficiency of the time for the performance of a specific procedural action must be carried out in each case individually, taking into account the circumstances of the case..$^{20}$ Moreover, procedural law defines additional criteria for the reasonableness of procedural time set by the court.

Thus, according to Part 7 of Art. 178 of the CPC, the revocation is filed within the period established by the court, which may not be less than fifteen days from the date of service of the decision, to initiate proceedings. The court must set a time limit for filing a notice that will allow the defendant to prepare it and the relevant evidence and the other participants in the case to receive a notice no later than the first preparatory hearing in the case. If the defendant does not provide a revocation within the period established by the court without good reason, the court decides the case on merits.

As stated in Part 4 of Art. 179 of the CPC, the response to the revocation shall be filed within the period prescribed by the court. The court should set a time limit for filing a response to the revocation, which will provide sufficient time for the plaintiffs to prepare their arguments and the relevant evidence, for the other participants in the case - to receive a response to the revocation in advance before the trial on merits, and for the defendant - to provide objections to the parties before the trial.

According to Part 4 of Art. 180 the CPC states that objection is filed within the period prescribed by the court. The court must set a time limit for filing an objection that will allow other participants in the case to receive an objection in advance of the hearing of the case on merits. Part 4 of Art. 181 of the CPC specifies that explanations of a third party are submitted within the period prescribed by the court. The court must set a time limit that will allow the third party to prepare its arguments and relevant evidence and provide explanations to the claim or revocation, and other parties to the case - to respond to such explanations in advance of the consideration of the case on the merits.

The reasonableness of procedural time limit is inextricably linked to their duration, which is a certain value of the time interval between two points in time (the beginning of the procedural time and the end of the procedural time). The duration of procedural time is determined using the methods of calculation established by law (Art. 122 of the CPC of Ukraine) and the rules on the beginning and end of procedural time (Art.s 123, 124 of the CPC of Ukraine) and their renewal and extension (Art. 127 of the CPC of Ukraine). In addition, to characterize the procedural time, it is necessary to highlight such concepts as the beginning of the procedural time limit.

The beginning of the procedural time limit is the relevant calendar date or the occurrence of the event since which it begins. A separate property of the procedural time limit is its uniformity. This means that both the legislator and the court setting the duration of

20 See more in: VV Komarov (ed) and others, Kurs tsuvilnoho protsesu [Course of civil procedure] (Pravo 2011); MY Shtefan, Tsuvilne protsesualne pravo Ukrainy [Civil procedural law of Ukraine] (Publishing house 'In Jure' 2005). 
specific procedural time can apply only one value of the calculation, which is provided for in Art. 122 of the CPC.

In this regard, it should be noted that courts do not always adhere to this feature of procedural time limit. The most common violations of this feature of the time limit set by the court include the setting of a time limit to eliminate the shortcomings of the statement of claim (appeal or cassation appeal). Thus, the Cassation Civil Court of the Supreme Court (hereinafter - the CCC of the Supreme Court) in its decision determines the time by the following method of calculation: until 23 March 2018, but not exceeding ten days from the date of delivery of the relevant resolution. ${ }^{21}$

In another decision, the CCC of the Supreme Court set the time as follows: one month to fullfil the requirements of the resolution, but not later than ten days after the end of quarantine established by the Cabinet of Ministers of Ukraine to prevent the spread of coronavirus disease (COVID-19). ${ }^{22}$ Even more interesting is the example of extending the previously established time limit by defining the time limit in the following way: until 10 August 2020, but not exceeding ten days from the date of service of this decision and the end of quarantine established by the Cabinet of Ministers of Ukraine to prevent the spread of coronavirus disease (COVID-19). ${ }^{23}$

In all of the above examples, the court sets a time limit for eliminating the shortcomings of the cassation appeal by means of two values for the calculation of procedural time. Thus, in the first case, the court uses an indication both by an event that must inevitably occur and in days, in the second case - in months and days, and in the third case the procedural time limit is set by the court using an indication of an event that must inevitably occur and in days with not quite appropriate wording of the automatic extension of time by the court in accordance with Law № 540-IX. The consequence of violation by courts of such a feature of the procedural time limit as uniformity is uncertainty for the parties to the case, which of the above dimensions of calculation of time limit is mandatory for them, as well as the inconsistency of the time set by the court with the reasonableness of procedural time.

The Plenum of the Supreme Specialized Court of Ukraine for Civil and Criminal Cases in the decision of 17 October 2014 № 11 'On Some Issues of Compliance With Reasonable Time Limits for Civil, Criminal Cases and Cases of Administrative Offenses ${ }^{24}$ drew attention to the fact that the time limits set by the court (for example, the time for eliminating the shortcomings of the statement of claim or appeal), must comply with the principle of reasonableness. In particular, noting that when determining (at its own discretion) the duration of these time limits, the court must take into account the principles of dispositivnes and adversarialism, time limits set by law to consider the case when determining the time

21 Case 279/2481/16-ц (Supreme Court of Ukraine, 26 February 2018) <http://www.reyestr.court.gov.ua/ Review/72561130> accessed 08 July 2020.

22 Court decision < http:// www. reyestr. court. gov. ua. /Review/ 90021561> accessed 08 July 2020.

23 Court decision < http:// www. reyestr. court. gov. ua. /Review/ 90021550> accessed 08 July 2020.

24 The Resolution of the Plenum of the Supreme Specialized Court of Ukraine for Civil and Criminal Cases of 17 October 2014 № 11 'On some issues of compliance with reasonable time limits for consideration by courts of civil, criminal cases and cases of administrative offenses' $<$ https://zakon.rada.gov.ua/laws/show/ v0011740-14\#Text> accessed 08 July 2020. 
limit of specific proceedings, complexity of the case, number of participants, possible difficulties in claiming and examination of evidence, etc. The period that is objectively necessary for the performance of procedural actions, preventing violations of Art. 6 when making procedural decisions and consideration and resolution of the case in order to ensure timely (without undue delay) judicial protection is considered particularly reasonable. ${ }^{25} \mathrm{In}$ addition, to prevent violations of Art. 6 of the Convention for the Protection of Human Rights and Fundamental Freedoms, the establishment by the court of procedural burdens, in the form of time limits, must be clear and predictable from the point of view of the party to the proceedings, i.e. to comply with the principle of legal certainty. ${ }^{26}$

\section{OBSERVATION OF PROCEDURAL TIME LIMITS UNDER QUARANTINE CONDITIONS: EXPERIENCE OF UKRAINIAN LEGISLATION AND NATIONAL COURTS}

Law № 540-IX and Law № 731-IX have made some changes to the traditional understanding of the renewal and extension of procedural time limits.

For a long time, in scientific literature ${ }^{27}$ and case law the renewal of the procedural time established by law was allowed in accordance with Art. 127 of the CPC, provided that the court finds the reasons for its omission valid, with the exception when the impossibility of such renewal was established by the CPC. The extension of procedural time limit established by the court was allowed by the application of the party filed before the expiration of this time, or by court's initiative. However, the scientific literature actively discusses the issue of improving the procedure for renewal and extension of procedural time limits, in particular, by improving the current civil procedural legislation. ${ }^{28}$ For example, attention is drawn to the groundlessness of the conclusion on the distinction between the concepts of 'renewal of procedural time limit' and 'extension of procedural time limit' in connection with the division of time limits into statutory and court-appointed. ${ }^{29}$

The introduction of the amendments to the Procedural Codes had, indeed, a worthy purpose for the period of the established restrictions related to quarantine, to protect the interests of the participants in court proceedings, by automatically extending the basic procedural and some official time limits.

But this approach to quarantine-related restrictions has almost halted legal proceedings, which, in turn, has deprived most people whose rights have been violated of justice in a timely manner. Thus, in the methodological recommendations the CCC of the Supreme Court notes that, due to the fact that the commission of procedural actions and making court decisions by the legislator is made dependent on the commission of appropriate actions by the parties, it may lead to the fact that in some cases the court will not be

25 Resolution (n 24).

26 Kravchenko v. Ukraine (App No 46673/06) ECHR 30 June $2016<$ https://zakon.rada.gov.ua/laws/ show/974_d47\#Text> accessed 08 July 2020.

27 See more in Komarov (n 20), Shtefan (n 20).

28 Komarov (n 20).

29 OM Borshchevska, 'Stroky u hospodarskomu sudochynstvi' ['Time limits in commercial litigation'] (Candidate of Law thesis, NAS of Ukraine, Institute of Economic and Legal Research 2016). 
able to consider cases, resolve another procedural issue or make a court decision without violating the rights of a party to the case. That is, until the end of the quarantine, the courts may not consider cases in which the 'obligated' party has not taken the procedural action expected of it or has not exercised the procedural rights granted to it. ${ }^{30}$

In addition, in our opinion, it is impossible to protect the interests of the parties during the quarantine period only by automatically extending the procedural time. As noted, the extension of procedural time belongs to the institution of procedural time and is closely related to such a feature of procedural time as its duration. The essence of the extension of procedural time is to increase the duration of the previously established time, and such an increase may be accomplished by either setting a new time limit or by increasing the previously established time limit.

The CCC of the Supreme Court provided the courts with methodological information on controversial issues of the application of the legislation on extension of procedural time limits during quarantine, ${ }^{31}$ noting, in particular, that these legislative changes came into force upon publication of Law № 540-IX, , $^{32}$ i.e. on 2 April 2 2020. However, given the content of Art. 3 of the CPC of Ukraine and the fact that the proposed changes do not establish new responsibilities, do not cancel or restrict the rights of litigants, do not restrict their use, they have a retroactive effect, i.e. they apply to legal relations connected to the implementation of proceedings in all cases, i.e. those that are already pending in the courts of all instances and those that will be opened in the future. In this case, the date of the beginning of quarantine throughout Ukraine does not matter if the civil procedural legal relationship continues.

Procedural actions of the court and participants in the trial should be carried out only within the relevant stages of the proceedings, in sequence and within a certain time, including procedural time limits for litigants and court time limits established by law for the court (official time limits). Law № 540-IX stipulates that the procedural time limits in the cases determined by it are not suspended and not renewed, but are automatically extended.

Despite the fact that the text of Law № 540-IX refers to the extension of procedural time limits, i.e. the time limits set for the parties to the proceedings for taking procedural actions, the extension also applies to some official time limits, such as time limits for court making decisions, time limits for the court considering applications and petitions and the time limit of consideration of the case under simplified procedure.

However, in contrast to the procedural time limits, the extension of which is absolute, the service time limits are extended only if the commission of a procedural action by a judge (court) depends on the commission or non-commission of certain procedural actions by the parties. In other words, the amendments do not relieve the judge (court) from the obligation to perform procedural actions and make appropriate procedural

30 Supreme Court, 'Methodical information on controversial issues of application of the legislation on extension of procedural times during quarantine' (22 April 2020) <https://supreme.court.gov.ua/supreme/ pres-centr/news/928802)> accessed 08 July 2020.

31 Supreme Court (n 30).

32 The Law (n 17). 
decisions within the time limits expressly provided by the CPC of Ukraine, if the parties have properly performed their duties and exercised their rights.

At the same time, taking into account that according to the general rule, the CPC of Ukraine does not impose the dependence of procedural actions by a judge (court) or the adoption of a relevant court decision on commencement of procedural actions by the parties, in this case, according to the logic of legislative changes, the beginning of official time limit has to be calculated from the moment of committing appropriate procedural actions by the parties to the case.

In order to respect the rights of the parties to the case, it is considered appropriate in each court decision to inform (explain, as a party to the process may often not know) the parties about the extension of procedural time limits and to outline a certain approximate time, for example, to indicate: 'within ten days from the moment of receiving a copy of the court decision, but not later than at the end of the quarantine period. However, it should be borne in mind that the commission of procedural actions after this period will still be considered lawful in the context of the above law.

Therefore, the time limit established in the court decision cannot be less than the duration of the quarantine. If the procedural time limit began before 12 March 2020, its duration will be equal to: the number of days of the time limit specified by law, which had passed before 12 March $2020+$ the quarantine period + the number of days remaining from the period established by law.

The following may serve as an example. The time for appealing a court decision is 30 days. 15 days had passed before the start of quarantine from the 30-day period specified by law. The total time for appeal, taking into account the provisions of Law 540-IX will be: $15+$ quarantine period +15 . If the procedural time limit began during the quarantine, its duration will be: the number of days before the end of quarantine + time limit established by law. That is, for the period of quarantine the calculation of procedural times is stopped.

Another example illustrates the beginning of the procedural time, which began during the quarantine. The time limit for the appeal began on 10 April 2020, thus, taking into account the effect of Law 540-IX, the time limit defined by law for the appeal should be calculated from the next day after the end of the quarantine, i.e. 30 days. This also applies to the calculation of the one-year procedural time limit for an appeal against a court decision (part two of Art. 358 of the CPC of Ukraine). If the party to the case has the right to perform a procedural action during the quarantine, the procedural time begins on the day following the end of the quarantine in the full extent established by law (or court).

The first part of Art. 273 of the CPC of Ukraine provides that the court decision enters into force after the expiration of the period for filing an appeal by all participants, provided that the appeal was not filed. In this regard, since in accordance with Art. 354 of the CPC of Ukraine the time for an appeal is extended until the end of the quarantine period, all court decisions of the courts of first instance, which were made during the quarantine, will take effect only after its expiration, i.e. when the time for appeal expires. This also applies to court orders and court decisions in absentia. 
However, since Art.s 384 and 419 of the CPC of Ukraine stipulate that a decision of a court of appeal or cassation takes legal effect from the date of its adoption, the above Law № 540-IX does not affect the legal force of court decisions of appellate courts.

As the times for review and appeal of court decisions are extended until the end of quarantine by Law № 540-IX, submission of applications and complaints without compliance with the time limits provided by the CPC of Ukraine until the end of quarantine will not be considered as grounds for leaving such applications and complaints without action, as, according to the above mentioned law, they are submitted in a timely manner. Accordingly, individuals should not apply for the renewal of a missed time limit.

However, this does not apply to situations where the procedural time limit was missed before the quarantine was announced. That is, if the procedural time limit had expired by $12 \mathrm{March}$ 2020, the effect of Law 540-IX does not change it. However, the reference to the fact that the person missed the time limit due to the quarantine, can be considered as a valid reason.

According to Law № 540-IX, the time for which the procedural time limits have been extended is determined by the duration of the quarantine, i.e. by the moment when the Cabinet of Ministers of Ukraine adopts an official decision on its termination. Accordingly, in the operative part of the court decision, which sets the time limit for procedural actions, in addition to specifying the procedural time limit, it is advisable to use the legislative wording, namely 'until the end of the quarantine period'.

The analysis of the methodological information on the application of the provisions of Law № 540-IX shows that in the Supreme Court it was difficult to find a clear formula for extending the procedural time limits. Thus, the Supreme Court points out that Law № 540-IX stipulates that procedural time limits in certain cases are neither suspended, nor renewed, but automatically extended, the time established in the court decision may not be less than the duration of quarantine, i.e. the calculation of procedural time limit is suspended for the quarantine period.

Indeed, according to the general rules of the $\mathrm{CPC}$, it is possible to extend the procedural time limit, which has already begun, but not yet ended. The extension of procedural time limits is associated with the establishment of additional time or an increase in the period of time for the performance of procedural actions. Accordingly, in contrast to the renewal of procedural time, when deciding on the extension of the time limit, there is no obligation to simultaneously apply for the extension of time limit and perform a procedural action whose deadline is to be extended. When extending the procedural time limit, the procedural action may be committed at any time from the beginning of the initially established time to the expiration of the additional or new time.

In this sense, the Supreme Court notes that time limits are not stopped. The consequence of the suspension of the procedural time limit is the suspension of the flow of the procedural time limits, and, accordingly, from the moment of suspension and until the day of resuming the procedural time, the right to perform a procedural action is lost. At the same time, in our opinion, the conclusion of the Supreme Court that the calculation of procedural time limit is suspended is inappropriate. In the context of Art. 122 of the CPC, the calculation of procedural time limit should be considered as units of measurement of the duration of the time defined by law. 
Thus, the time limits established by law or court are calculated in years, months, days, or can be determined by an indication of an event that must inevitably occur (Art. 122 of the CPC). Such an understanding by the Supreme Court of the extension of procedural time limits does not correspond either to the notion of extension of time limit nor to the suspension of the calculation of procedural time, which has not at all been used in the legal literature and practice before.

In addition, the understanding of the extension of the procedural time limit is also negatively affected by the new practice of the Supreme Court to apply certain provisions of procedural law. Thus, the Commercial Court of Cassation of the Supreme Court notes that the analysis of these rules gives grounds to conclude that failure to eliminate the above shortcomings of the appeal within the period specified in the decision of the Court of Appeal on leaving the appeal without action, has the effect of returning the appeal.

Part 2 of Art. 174 of the Commercial Procedural Code of Ukraine sets a time limit for eliminating the shortcomings of an application/complaint which cannot be extended by the court. Therefore, the ten-day time granted by the Court of Appeal to the defendant by the court ruling of 26 February 2018 to eliminate the deficiencies of the appeal cannot be extended, which accordingly makes it impossible to satisfy the defendant's application to extend the time to eliminate the deficiencies of the appeal.

Having come to the right conclusion on this, the Court of Appeal declines the arguments of the plaintiff on deprivation of his/her access to justice due to non-extension by the appellate court of the time for elimination of shortcomings.

Moreover, in regards to the applicant's allegation that the Court of Appeal had deprived him of access to justice, the court considers it necessary to add the following. Art. 129 of the Constitution of Ukraine establishes the basic principles of judicial proceedings, which, in particular, are the provision of appeals and cassation appeals against court decisions, except in cases established by law.

However, the right to a court, one aspect of which is the right of access to a court, is not absolute, it may be subject to restrictions in its content, especially in regards to the conditions for the admissibility of an appeal against a decision. However, such restrictions may not confine the exercise of this right in such a way or to such an extent that the very essence of the right is violated ${ }^{33}$.

These restrictions must pursue a legitimate aim and there must be a reasonable degree of proportionality between the means employed and the objectives pursued. The rules governing the time limits for filing complaints are, of course, intended to ensure the proper administration of justice and the principle of legal certainty. Their application must comply with the principle of legal certainty and not prevent the parties from using available means; concerned parties should expect that these rules will be applied

33 See Ponomaryov v. Ukraine (App no 3236/03) ECHR 3 April 2008 para 41 <http://hudoc.echr.coe. int/fre? $\mathrm{i}=001-85683>$ accessed 08 July 2020: 'The Court acknowledges that it is primarily within the domestic courts' discretion to decide on the renewal of the time-limit for an appeal, but such discretion is not unlimited. The courts shall be required to indicate the reasons' and Aleksandr Shevchenko v. Ukraine (App no 8371/02) ECHR April 2007 para $27<$ http://hudoc.echr.coe.int/eng?i=001-80286> accessed 08 July 2020. 
(judgment of the European Court of Human Rights of 18 November 2010 in the case of Mushta vs Ukraine ${ }^{34}$ ). The return of the appeal against the decision of the court of first instance does not deprive the appellant of the right to re-appeal. ${ }^{35}$

The automatic extension of the procedural time limits provided by Law № 540-IX has led to the postponement of the consideration of the majority of civil cases and the postponement of the decision entry into force for an indefinite period. But in our view, even in the midst of the pandemic, the courts must perform basic functions and ensure justice. Such automatic extension of procedural time created conditions for abuse of procedural rights and has led to the impossibility to obtain judicial protection, including the stage of the decision entry into force.

Law 731-IX is aimed at overcoming the negative situation that has arisen in the field of justice in civil cases related to the automatic extension of procedural time limits. Thus, in accordance with the provisions of this Law, the court on the application of the parties and persons who did not participate in the case, if the court decided on their rights, interests and (or) responsibilities (if they have the right to take appropriate procedural actions provided for by this Code), renews the procedural time established by the norms of this Code, if it recognizes the reasons for their missing the deadline as valid and due to the restrictions imposed caused by quarantine. The court may renew the relevant time limit both before and after its expiration. Upon the application of a person, the court shall extend the procedural time limit established by the court, if the impossibility to perform the relevant procedural action within the specified time is due to the restrictions engendered by the quarantine.

It should be noted that the legislature again departs from the understanding of renewal and extension of procedural time limits, which is enshrined in the CPC. Thus, according to Art. 127 of the CPC, the court on the application of the party to the case renews the missed procedural time limit established by law, if it finds the reasons for missing the deadline valid, except when the CPC establishes the impossibility of such renewal.

The procedural time established by the court may be extended by the court upon the application of the party to the case, submitted before the expiration of this time, or on the initiative of the court. Unless otherwise provided by law, the application for renewal of the procedural time established by law shall be considered by the court, where the procedural action in respect to the time limit was missed, is to be performed and the application for extension of the procedural time established by the court shall be considered by the court, which established the time without notifying of all of the participants of the case.

Simultaneously with the submission of the application for renewal of the procedural time, a procedural action (submitted application, complaint, documents, etc.) in respect to the deadline missed must be performed. Missing the time limit set by law or court for a party to the case to present evidence, other materials or take certain actions does not release such a party from the obligation to take the appropriate procedural action. The court shall issue a ruling on the renewal or extension of the procedural time. The court

34 Mushta v. Ukraine (App no 8863/06) ECHR 18 November $2010<$ http://hudoc.echr.coe.int/ eng?i=001-101769> accessed 08 July 2020.

35 Court decision < http:// www. reyestr. court. gov. ua./Review/74456005> accessed 08 July 2020. 
shall issue a ruling on the refusal to renew or extend the procedural time, which shall be sent to the person who filed the relevant application no later than the next day from the day of its ruling. The decision to refuse to renew or extend the procedural time may be appealed in the manner prescribed by this CPC.

Thus, the CPC associates the renewal of the procedural time with the missing of the time limit established by law and the consequences provided for in Art. 126 of the CPC. According to Art. 126 of the CPC, the right to perform a procedural action is lost after the expiration of the timeframe established by law or the court. Documents submitted after the expiration of the procedural time limit remain without consideration, except as provided by this CPC. In this regard, as noted earlier, the CPC requires that at the same time as filing an application for renewal of the procedural time, a procedural action must be taken (submitting of application, complaint, documents, etc.) in respect to the deadline was missed. In addition, the only ground for renewing the procedural time limits in accordance with the CPC is the court's recognition of the seriousness of the reasons for its being missed.

Unlike the renewal, the procedural time limits set by the court are subject to extension. It is related to the duration of the time limit, which has not yet passed. Continuation is possible both at the request of the party to the case and on the initiative of the court.

In this regard, it is not clear why Law 731-IX deviates from the general provisions of the CPC regarding the renewal and extension of procedural time limits. For example, in accordance with Law 731-IX, the court may renew the relevant period both before and after its expiration. The main idea of the Law 731-IX is the refusal of automatic extension of procedural time limits. According to Law 731-IX, the grounds for renewal and extension of procedural time limits are the recognition of the reason for their being missed by the court as valid and due to the restrictions imposed by the quarantine.

According to Law 731-IX, the extended procedural time limits expire 20 days after the entry into force of this Law. During this 20-day period, the parties to the case and persons who did not participate in the case, if the court has decided on their rights, interests and (or) responsibilities (if they have the right to take appropriate procedural actions under these codes), have the right to extend the procedural time limits on the grounds established by this Law.

According to Law № 540-IX, the amount of time for which the procedural time limits are automatically extended is determined by the time of quarantine expiration, i.e. the moment when the Cabinet of Ministers of Ukraine makes a formal decision on its termination. According to the Law, for time limits that have already been automatically extended, where in each court decision an explanation was issued to extend the procedural time limits and where a certain approximate time is outlined, it is established that the specified time expires 20 days after the entry into force of this Law. In addition, the court at the request of the party to the case and the person who did not participate in the case, if the court has decided on their rights, interests and (or) responsibilities (if they have the right to take appropriate procedural actions under these CPC), filed within the same 20-day period, extends the procedural time limit established by law or the court for the period of quarantine. That is, these provisions of the Law set new time limits for the commission of procedural actions by the parties to the case, in connection with which, in our opinion, there are doubts about the compliance of these provisions 
with Part 4 of Art. 3 of the CPC, according to which the law establishes new obligations, cancels or narrows the rights belonging to participants in court proceedings or restricts their use, has no retroactive effect.

It is worth noting that the ECtHR made its conclusion in similar circumstances. Thus, in Peretyaka and Sheremetyev vs Ukraine, it is a notable fact that the appellate courts had considered the applicants' cases particularly in civil proceedings, which was important in these circumstances ${ }^{36}$. In addition, their decisions clearly stated that a cassation appeal should be lodged with the Supreme Court within two months, i.e. within the time allowed for appealing by the new rules of civil procedure.

Thus, the appellate courts unequivocally directed the applicants to pursue their cases in civil proceedings (see paragraphs 7, 12 and 22 above). Even if the operative part of the judgment could not be considered binding for the court of the next instance, the appellate courts' assertion that the applicants had two months to appeal, was the only thing they could rely on, in particular in view of the fact that the relevant events took place immediately after significant changes in procedural law. In view of the above, the Court concludes that the Supreme Administrative Court's decision to apply a period of one month to each case, which led to the applicants' failure to consider the merits of the cassation appeals, was disproportionate to the purpose of the procedural restriction in question.

\section{CONCLUDING REMARKS}

The COVID-19 pandemic is a health care crisis with serious human and social consequences, with challenges for the courts and the judiciary in Member States. It has created the conditions to reflect on the possibilities of applying innovative measures in the judiciary. ${ }^{37}$

In the context of domestic realities, we note that the gaps in the procedural legislation and other technical and legal shortcomings of the rules and institutions of civil procedural law significantly affect the access to justice. Inaccuracy and incompleteness in resolving issues important for the administration of justice in quarantine conditions related to the extension and renewal of procedural time limits creates obstacles for the implementation of the main tasks of civil proceedings. Inaccuracy in the regulation of procedural legislation of certain procedural time limits, the possibility of their renewal and extension can significantly affect the movement of all civil proceedings and, to a great extent, impede the achievement of its goals.

In this regard, in our opinion, the improvement of procedural norms of the CPC of Ukraine in the part of procedural time limits during the quarantine established by the Cabinet of Ministers of Ukraine for the prevention of coronavirus disease (COVID-19), which aims to prevent the negative effects of missing deadlines and incurring procedural consequences, has led to a lowering of certain standards and a violation of legal guarantees.

36 Peretyaka and Sheremetyev v. Ukraine (App nos. 17160/06 and 35548/06) ECHR 21 December 2010 $<$ http://hudoc.echr.coe.int/eng?i=001-102447> accessed 08 July 2020.

37 CEPEJ, 'Lessons Learnt and Challenges Faced by the Judiciary during and after the COVID-19 Pandemic' (10 June 2020) CEPEJ 8rev) <https://rm.coe.int/declaration-en/16809eale2> accessed 08 July 2020. 